\title{
Appraising Spatio-Temporal Shifting of Urban Growth Center of Pimpri-Chinchwad Industrialized City, India Using Shannon Entropy Method
}

\author{
R. S. Ranpise1, A. K. Kadam¹, S. W. Gaikwad'2, D. C. Meshram³ \\ ${ }^{1}$ Department of Environmental Science, Savitribai Phule Pune University, Pune, India \\ ${ }^{2}$ Department of Geography, S. P. College, Pune, India \\ ${ }^{3}$ Department of Geology, Savitribai Phule Pune University, Pune, India \\ Email: rranpise@gmail.com
}

How to cite this paper: Ranpise, R. S., Kadam, A. K., Gaikwad, S. W., \& Meshram, D. C. (2016). Appraising Spatio-Temporal Shifting of Urban Growth Center of PimpriChinchwad Industrialized City, India Using Shannon Entropy Method. Current Urban Studies, 4, 343-355.

http://dx.doi.org/10.4236/cus.2016.43023

Received: August 11, 2016

Accepted: September 27, 2016

Published: September 30, 2016

Copyright $\odot 2016$ by authors and Scientific Research Publishing Inc. This work is licensed under the Creative Commons Attribution International License (CC BY 4.0).

http://creativecommons.org/licenses/by/4.0/

(c) (i) Open Access

\section{Abstract}

Uncontrolled urban development of Pimpri Chinchwad area was assessed to understand shifting of urban growth center and its controlling factors during last forty years. Out of forty, initial 20 years span (1973 to 1993) is compared to subsequent 20 years (1993 to 2013). The secondary data i.e. topographic maps (year 1970 and 2009) and satellite image MSS, LISS III (year 1973 and 1993) and LISS IV image (year 2013) were used for preparation of land use land cover maps. Furthermore, Shannon entropy computed by built-up land class, was showing the entropy $0.81,0.92$ and 0.97 for year 1973, 1993 and 2013 respectively, hence the steady growth during past forty years. However, growth centers of urban development shifts from automobile industries at Pimpri (central part) to information technology (IT) industries towards Hinjewadi (western part) area. This shift was determined from the demographic alteration in study area. To understand demographic alteration, the spatial results were verified through ground truth survey reveals population growth is in the form of vertical growth such as increase in multi storey buildings instead of single storey housing. This study highlights the shifting of urban growth centers in developing countries such as India from automobile to IT industries. The shifting of growth center was resulted into impact on existing public services (drinking water, sanitation, waste management, roads, hospitals etc.). In conclusion, present study warrants the attentions towards shifting of urban growth center from such rapidly growing industrial city of the developing countries while deciding future urban planning. 


\section{Keywords}

Urban Growth Center, Shannon Entropy, Industrialized City, Pimpri-Chinchwad, Sub-Urbanization

\section{Introduction}

Urbanization is a continuous growth process (Spence et al., 2009; Shabu, 2010) in rapidly developing urban areas, when it further grows leads to suburbanization (Champion, 2001) and subsequently influence shifting of urban growth center (Zhou, 1997; Hermelin, 2007). This shift can be monitoring by change in population density, jobs, services and trade at the edge of urban land (Zhou, 1997). The urban land is characterized by population size/density, lifestyle and occupation with which people involved (Bryant, 2003; Tsai, 2005; Weeks, 2010). However, urban center is a business activity area (Cortright, 2015; Dobbs \& Remes, 2012; Kotharkar et al., 2014) specifically area around post office or market area.

The spatial distribution of population is common around city center but random at sub-urban areas (Lie \& Zhang, 2009; Champion, 2001). The random spatial growth of built up land (generally the housing units) refers to urban sprawl (Glaeser \& Kahn, 2004; Sudhira et al., 2004; Glaeser et al., 2005). The sprawl and suburbanization are alternatively used terms in urban growth studies (Nechyba \& Walsh, 2004; Frenkel \& Ashkenazi, 2008). In suburbanization process population increases towards periphery region which further forms decentralization and later reversed called counter-urbanization (Zhou, 1997; Grigorescu et al., 2012). Suburbanization leading to shifting of urban growth centers is common in developing countries like Brazil, South Africa, South East Asia and in India (Brockerhoff, 1999; Tran et al., 2008; Guest \& Brown, 2005). There is hardly availability of any scientific data regarding assessment of shifting of urban growth centers, therefore a preliminary attempt has been made to assess the urban growth centers from Pimpri-Chincwad industrialized city in India, a representative of developing countries.

This study had focused spatio-temporal shifting pattern of urban growth centers with respect to their possible reasons of initiation. The possible reasons hypothesized to be shifting of employment centers, infrastructures and increase in soft skill education in developing countries. To verify, quantify and confirm the reasons of urban growth shifting following objectives were assigned, 1) use of Shannon Entropy to assess the spreading behavior of urban area by spatio-temporal manner, 2) to know the spatiotemporal demographic alteration of study area, 3) to verify geospatial results with appropriate ground truth verification for accuracy assessment, 4) to identify the reasons behind shifting of urban growth centers in study area, and 5) to suggest BMP's (Best Management Practice's) for development of such urban growth shifted area at its early stages. 


\section{Study Area}

Pimpri Chinchwad is a rapidly developing city of Maharashtra state, India, known for large number industries (more than 4086 large, medium and small scale industries (CDP, 2006; ESR, 2012-2013). The study area shown in Figure 1 lies is Pune district with total area of $176 \mathrm{sq} \cdot \mathrm{km}$ and 105 administrative wards (Annex-I). Geographically it is located at $18^{\circ} 37^{\prime} 07.04^{\prime \prime}$ in $\mathrm{N}$ and $73^{\circ} 48^{\prime} 13.43^{\prime \prime} \mathrm{E}$ of western margin of the Deccan Plateau towards leeward side of the Sahyadri hill ranges (western ghat). The average height from the mean sea level is about $560 \mathrm{~m}$. The major natural drainage are formed by river Pavana flowing through centre, river Indrayani in North and river Mula at south of study area.

Population wise study area ranked $18^{\text {th }}$ in India (1.7 million) with an average growth rate of 104.39\% for last five decades (CDP, 2006; Census, 2011; ESR, 2013-2014). The urbanization and sub-urbanization processes are parallel and high density of population towards sub-urban parts (specially in last two decade) highlight rapid development of study area.
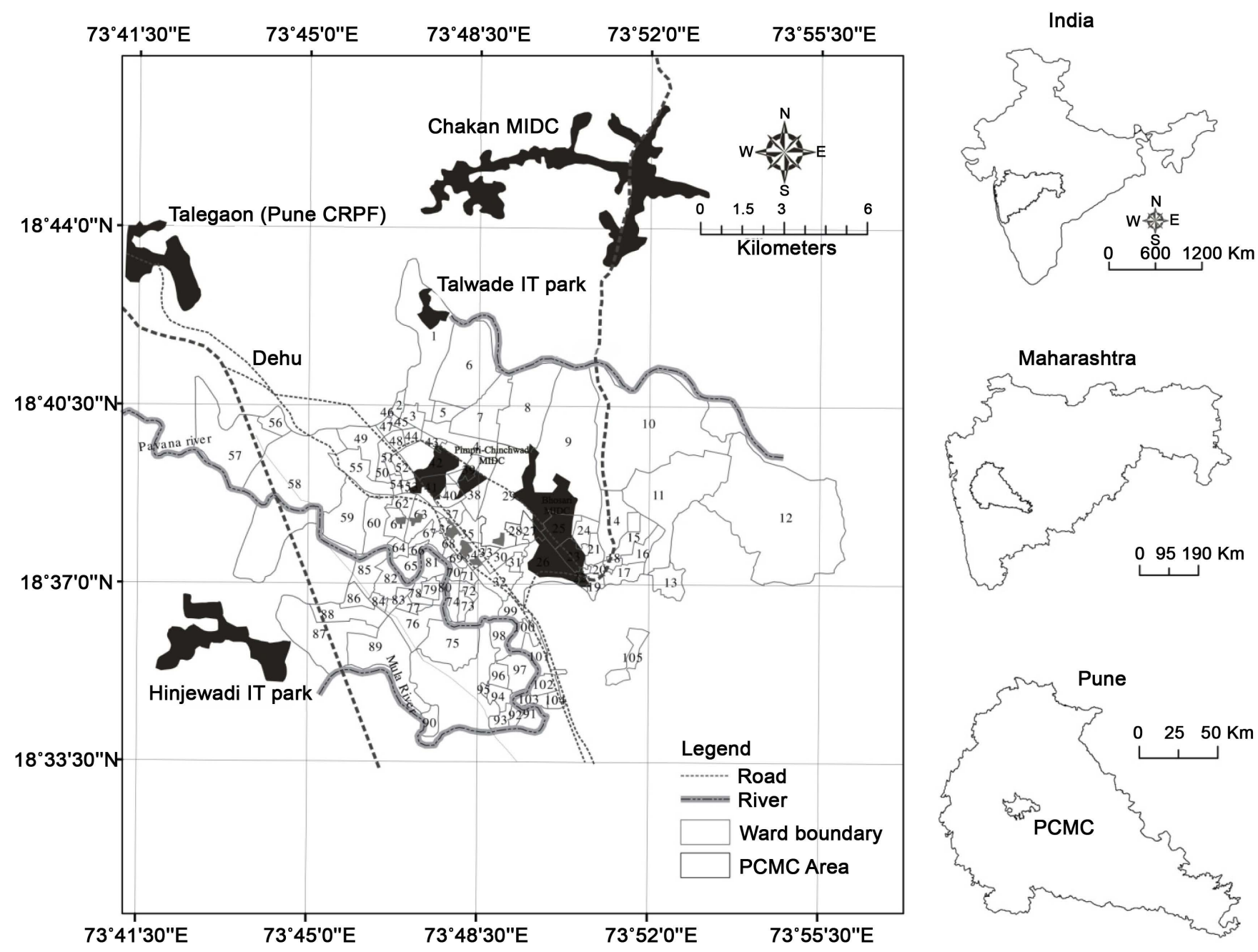

Figure 1. Detailed map of study area (PCMC). 


\section{Materials and Method}

Topological data (year 1970 and updated 2009) of 1:50000 scale showing land-use pattern were procured from Survey of India (SOI), Pune. The scanned raster data was georeferenced and digitized to convert it into usable form i.e. vector format (Ramchandran, 2000; Lee, 2014). Thematic (base) layers such as administrative boundaries, water bodies, residential and industrial areas were prepared using Arc-GIS 9.3.

Satellite images LISS III (1973 \& 1993) and LISS IV (2013) used for land use land cover study had been acquired from USGS \& NRSA Hyderabad. The geometric and radiometric corrections, image enhancement, rectification and re-sampling done prior to classification of satellite images. It helps to reduce the errors caused from different data acquiring periods, source of agencies, and spectral resolutions (Kumar, 2003). These images were processed further to supervised classification with maximum likelihood algorithm method in ERDAS imagine 9.2 (Anderson et al., 1976; Lubis \& Nakagoshi, 2011). The information extracted was the built up land, agricultural land, waste land, vegetation and water bodies.

The urban expansion assessment done by clipping thematic layers of toposheets data on to the classified satellite image in Arc-GIS 9.3 (Aguda \& Adegboyega, 2013; Dey \& Greeshma, 2014). The statistical information obtained in the form of attribute data was further used in quantifying built-up land and urban sprawl (Sudhira et al., 2004; Shekhar, 2004; Bhatta, 2010).

The non-spatial, i.e., secondary data (ward wise population data) had been used to ascertain changing population density at the periphery region. The spatial changes in built-up land were estimated through field survey and secondary data.

The Shannon's urban entropy measures the degree of spatial concentration and dispersal of built-up land between different time periods (Batty, 1974; Yeh \& Li, 2001; Shekhar, 2004; Alabi, 2009; Mohammady \& Delavar, 2015). The entropy was calculated first from the built-up land of individual ward and then sum total of 105 wards. For the measure of relative entropy $\left(\Delta E_{t}\right)$ a time scale $(t)$ of two decade had been considered. The entropy values range between 0 and 1 where, the maximum value 1 represents distribution of built up land across the space and the minimum value 0 is concentration of built-up land in one area.

Entropy $E_{t}$ and relative entropy $\Delta E_{t}$ (Bhatta et al., 2010; Pedro et al., 2013) were calculated using following equations where, $E_{t}$ is the entropy of study area, $D j$ density of land growth, $m$ is the total number of zones/wards of study area, and $P D j$ calculated from density of land of specific zone (ward) divided by total density of land growth. $\Delta E_{t}$ is the difference between two time periods it is a useful indicator to assess the magnitude of change of urban sprawl (Bhatta et al., 2010).

$$
\begin{gathered}
E_{t}=\frac{\sum_{j=1}^{m} P D j\left(\log \left(\frac{1}{P D j}\right)\right)}{\log (m)} \\
P D_{j}=\frac{D_{j}}{\sum_{j=1}^{m} D_{j}}
\end{gathered}
$$




$$
\Delta \mathrm{Et}=(t+1)-(t)
$$

Ground truth analysis: Ground truth survey of approximately 10 percent of study area were made to understand population shift, increasing number of settlements and distribution of population density. Hence, horizontal growth i.e. spreading of built up land in parallel directions with single or two storey housing units and vertical growth i.e. multi-storey buildings (floors-three and above) were marked from center to boundary of study area. Also new commercial establishments along the roads and periphery region had marked as new growth points.

\section{Results and Discussion}

Measuring Entropy to assess spreading behavior of study area:

The entropy is estimated using the sum total of entropy of 105 administrative wards calculated from built up land of individual ward in respective decade, shown in Table 1.

Year 1973 was showing lowest entropy (0.81) indicates minimum dispersal of built-up land. The built up land of year 1973 was accounting only residential or industrial land, in contrast, high entropy values in year 1993 (0.92) and 2013 (0.97) signifies urban sprawl (Yeh \& Li, 2001). The entropy result was showing a steady growth and continuous spreading of built up land in past forty years. Also, the change in population (98572 in 1971 to 1727692 in 2011), population density and increasing built-up land can be witnessed to urban growth of study area.

The temporal changes and degree of dispersal of land development i.e. urban sprawl is evaluated by change in entropy $\left(\Delta E_{t}\right)$ value. Results in Table 2 showed change in entropy value i.e. dispersal of land of development signify urban sprawl. A ribbon strip and leap frog type behavior of sprawl (Barnes et al., 2002) was observed in study area.

\subsection{Demographic Alteration and Spatio-Temporal Changes}

In past forty years population had increased 20.6 times, whereas built-up land grows about 25.83 percent. The industries present along old highway and railway line were

Table 1. Shannon's entropy 1973, 1993 and 2013.

\begin{tabular}{ccccc}
\hline Year & $\begin{array}{c}\text { Total area covered by } \\
\text { satellite image in sq. Km }\end{array}$ & $\begin{array}{c}\text { Total no. of } \\
\text { wards in PCMC }\end{array}$ & $\begin{array}{c}\text { Built-up area } \\
\text { in sq. Km }\end{array}$ & $\begin{array}{c}\text { Entropy } \\
\text { calculated as E }\end{array}$ \\
\hline 1973 & 170.38 & 105 & 03.09 & 0.81 \\
1993 & 170.38 & 105 & 20.42 & 0.92 \\
2013 & 170.38 & 105 & 43.43 & 0.97 \\
\hline
\end{tabular}

Table 2. Change in Entropy $\left(\Delta E_{t}\right)$.

\begin{tabular}{cccc}
\hline Sr. No. & Year & Entropy $E_{t}$ & Change in Entropy $\Delta E_{t}$ \\
\hline 1 & $1973-1993$ & 0.81 & 0.11 \\
2 & $1993-2013$ & 0.92 & 0.04 \\
3 & 2013 & 0.97 & \\
\hline
\end{tabular}


causing parallel residential growth. Clusters of built up land at central part, southern part, i.e., towards Pune city, and at village centers (now the wards) were seen in 1973 and 1993.

A constitutional amendment act (1992) and Jawaharlan Nehru National Urban Rural Mission (JNNURM) programme (2005) of India had been influencing the economic development (CDP, 2006) of study area.

The spatial changes as LULC (land use land cover change) from 1973-2013 have shown in Table 3, it represents urban growth pattern both in direction and magnitude of built up land (Sankhala \& Singh, 2014). A decreasing percentage of waste land, agriculture land, minute change in water bodies and increase of built-up land and vegetation were observed in LULC.

A simultaneous growth of population and built up land can be seen in Figure 2. It shows a linear forecast trend-line of percent growth of built-up land, non-built-up land and population growth. The percent built up land has been increasing at an alarming rate it shows $1.84 \%$ in $1973,12.14 \%$ in 1993 and $25.83 \%$ in 2013.

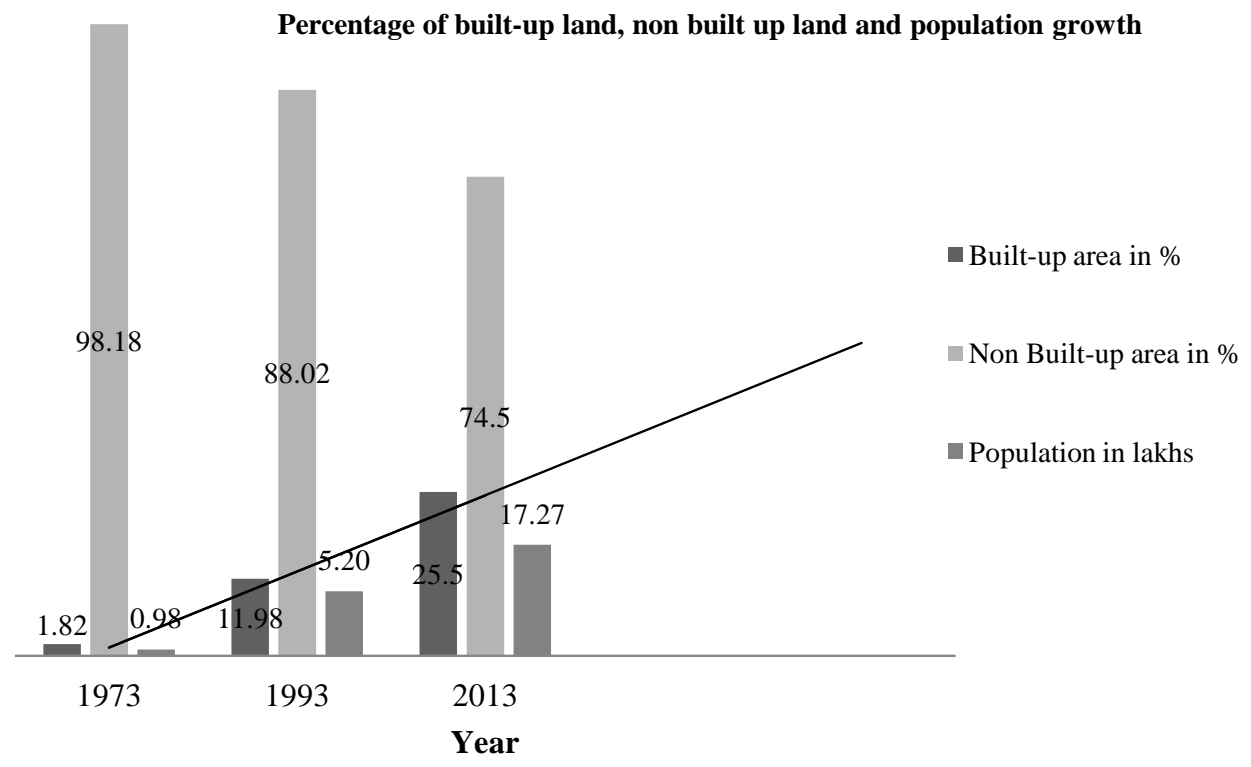

Figure 2. Percentage of built-up and non built up land in study area.

Table 3. Results of satellite image classified for year 1973, 1993 and 2013.

\begin{tabular}{cccccccc}
\hline \multirow{2}{*}{ Sr. No. } & Class name & \multicolumn{2}{c}{1973} & \multicolumn{2}{c}{1993} & \multicolumn{2}{c}{2013} \\
\cline { 3 - 8 } & & Area in Km ${ }^{2}$ & LULC \% & Area in $\mathrm{Km}^{2}$ & LULC \% & Area in Km ${ }^{2}$ & LULC \% \\
\hline 1 & Built-up land & 3.095 & 1.84 & 20.42 & 12.14 & 43.44 & 25.83 \\
2 & Water bodies & 1.89 & 1.12 & 2.09 & 1.24 & 2.12 & 1.26 \\
3 & Forest/Vegetation & 8.36 & 4.97 & 14.08 & 8.37 & 22.91 & 13.62 \\
4 & Agriculture land & 51.01 & 30.34 & 63.81 & 37.95 & 38.24 & 22.74 \\
5 & Waste land & 106.025 & 63.06 & 69.98 & 41.62 & 63.67 & 37.87 \\
& Total Area in & 170.38 & 100 & 170.38 & 100 & 170.38 & 100 \\
\hline & Km $/$ Percentage & & & & & &
\end{tabular}




\subsection{Population Density Shift}

As shown in Figure 3, Pimpri (ward No. 31\&32) and Chinchwad (ward No. 64, 65 \& 66) were the main villages (origin of city) in 1971 at the time of formation of municipal corporation and hence considered as urban center. It also shows the population spread around Pimpri, Chinchwad and other villages which are now become the wards of PCMC. The clusters of high population densities were observed at ward No. 46 - 61, 72, $73,77,79,90,91,95,96$ and 103 due to occurrence of industrial zone and available public facilities (bus stand, railway station, municipal offices, police station, schools, hospital and post office) in that period.

Figure 4 is showing population density in year 1991, where the high population density observed towards Nigdi Pradhikaran (residential) area. These areas are mainly coming under planned residential zone of PCMC (ward No. 2,3,4,5, 46, 47, 48, 49, 50, $52,55)$. Also the Bhosari and Moshi areas were showing high population density it can

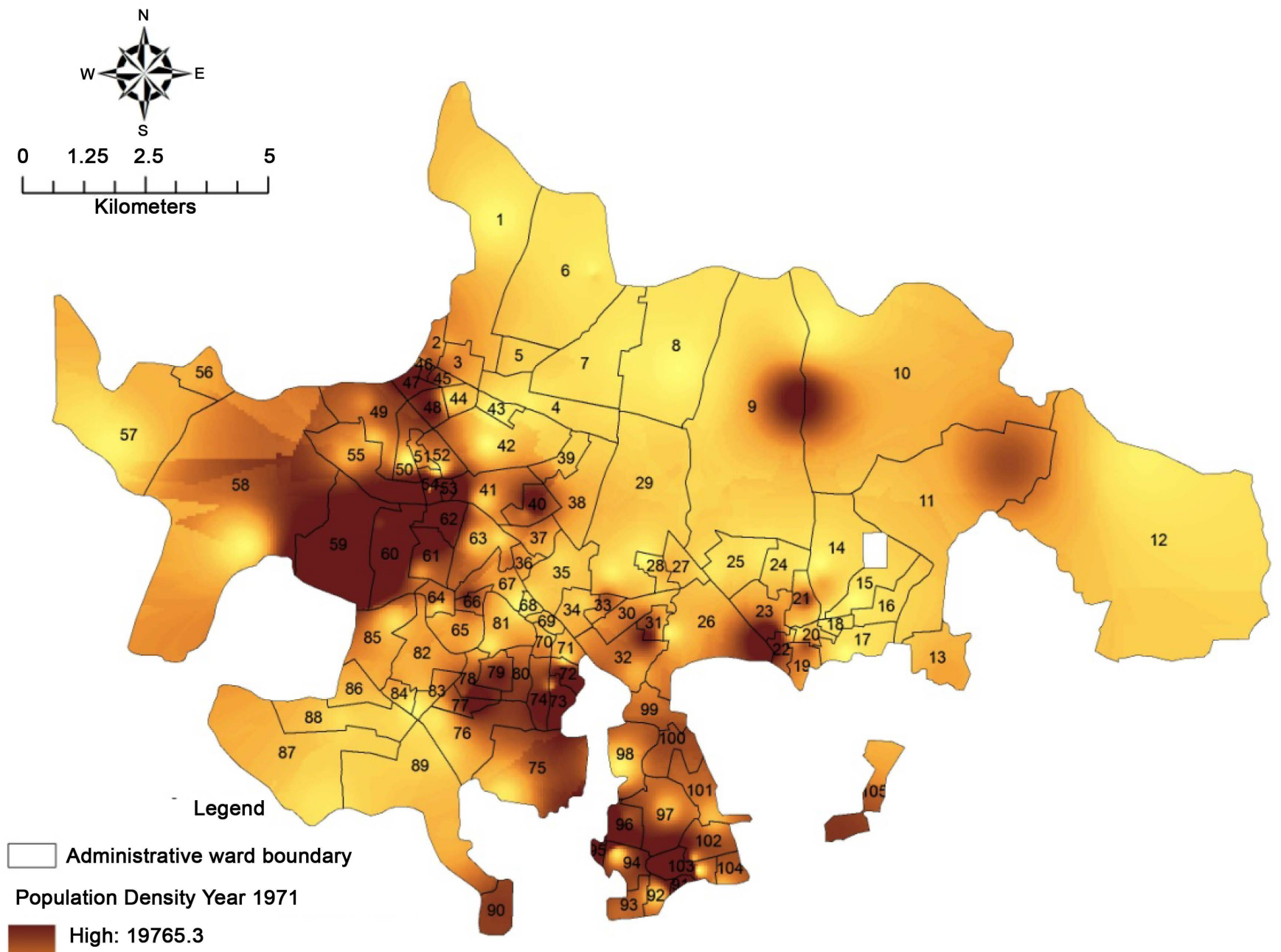

Low: 0.564115

Figure 3. Population density of study area in year 1971 . 


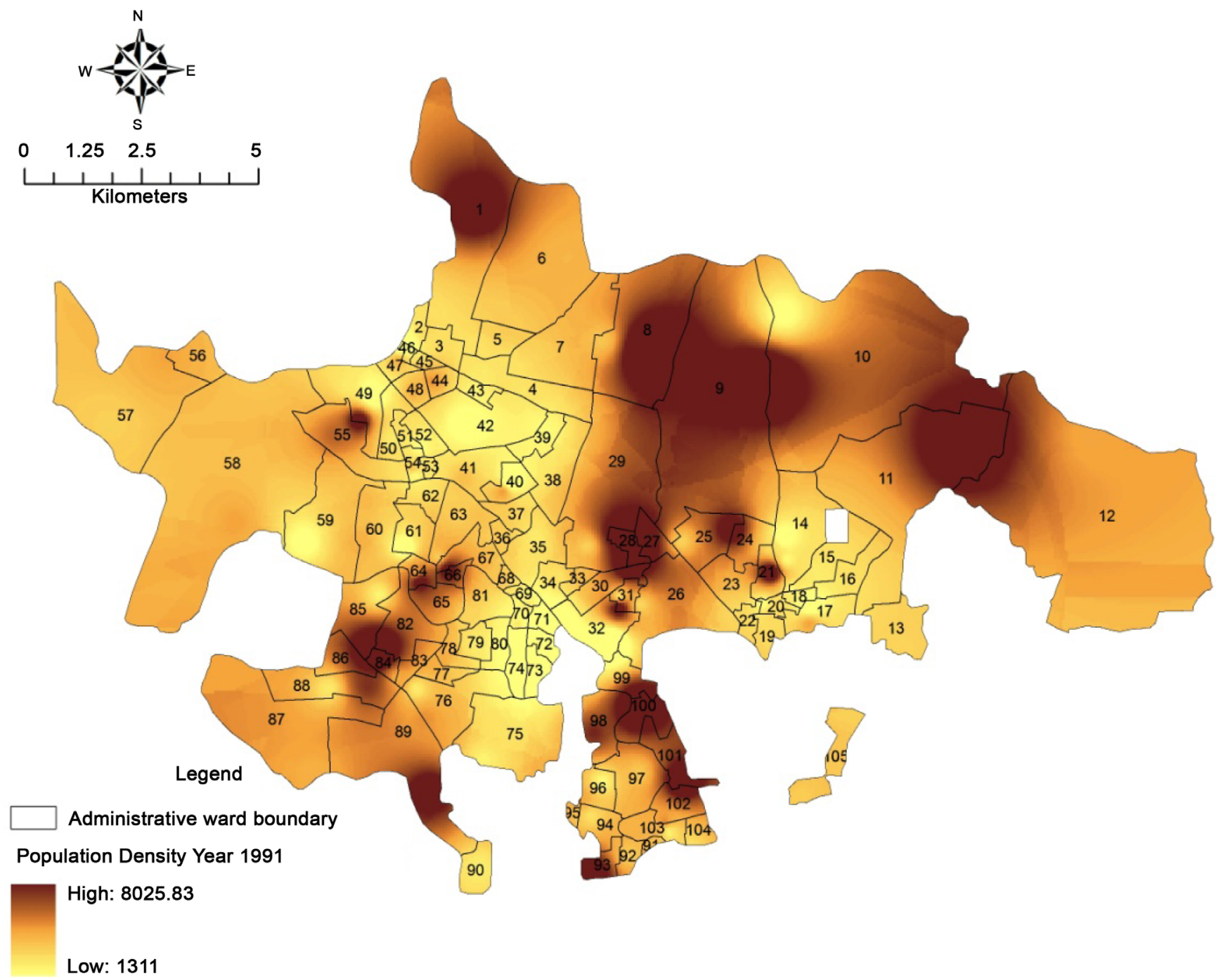

Figure 4. Population density of study area in year 1991.

be due to presence of a state highway (Pune-Nashik) and growing industries in Talavade and Chakan areas.

Figure 5 indicates high population density towards northern, south eastern and south part of study area. A clear shift of urban areas from Pimpri Chinchwad central to Wakad, Talavade, Chikhali was observed here. The economic pull (job opportunities) and infrastructural amenities (connectivity/accessibility) were attracting large population (internal and external) from urban to sub-urban localities (CDP, 2006-2012; ESR, 2013-2014) it becomes major cause of shift for migrating population.

\subsection{Ground Truth Survey}

Total 11.76\% area was surveyed from Pimpri-Chinchwad (assumed center). The housing units and shops (ground (G), G $+1, G+2$ and/or $G+3$ floor) around two major industries were going away from the assumed center. Where the patches of slum near 


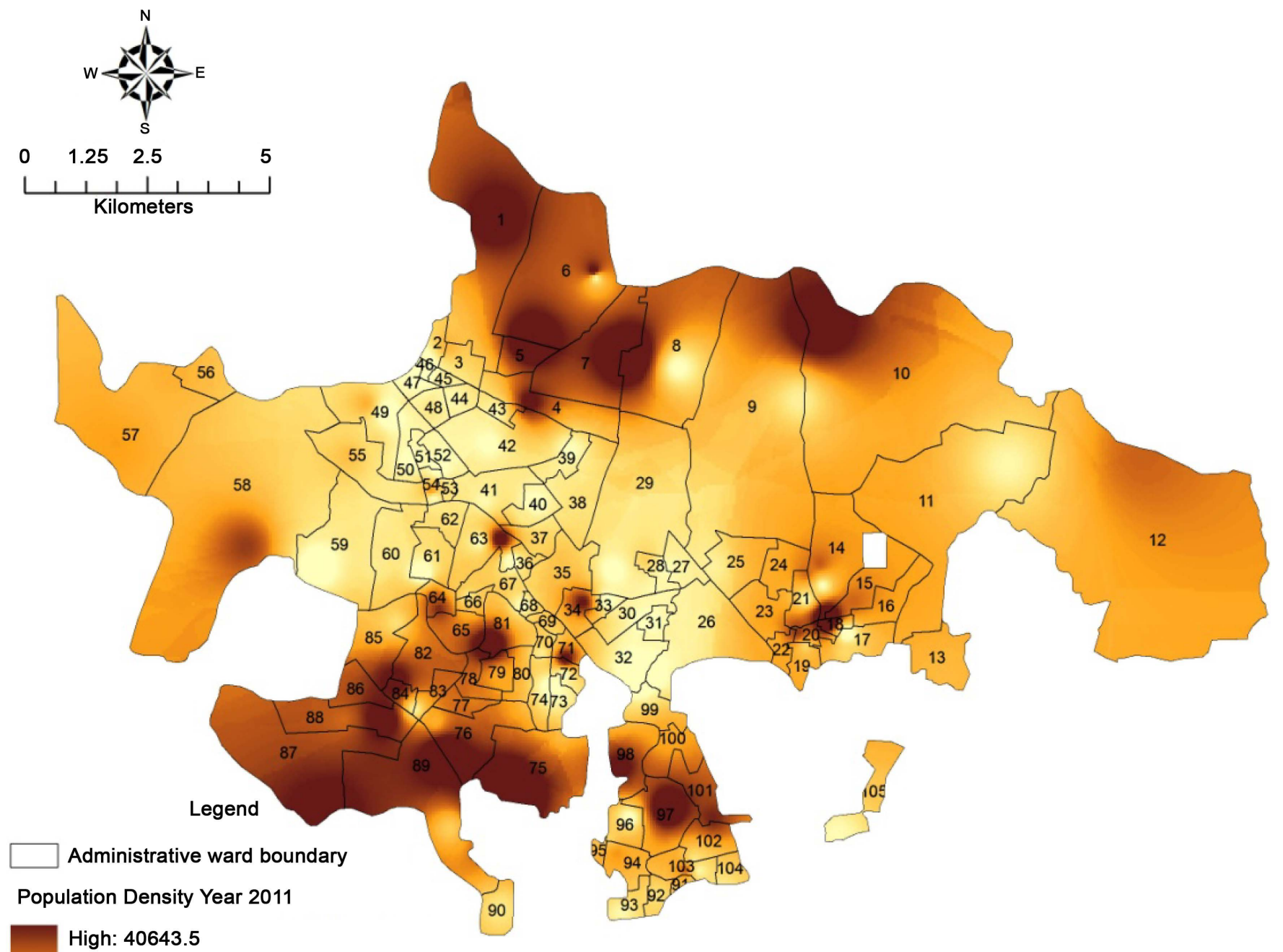

High: 40643.5

Low: 6111.16

Figure 5. Population density of study area in year 2011.

railway line and bus stands showed high population densities. The housing pattern of $G$ or $\mathrm{G}+1$ except few multi-storey buildings at central part was indicating leap frog type of sprawl.

A transition phase of urban center shifting noticed at south western part (Thergaon and Wakad villages) where the agriculture land was totally disappeared and transformed into built up land. The built up (residential) type of $G+5$ to $G+9 / 10 / 11$ in these areas is showing increases of population density and public service demands. This may ultimately causes formation of new urban center.

The urban areas marked by rivers and highway forming administrative boundary at wakad, nigdi and moshi as sub-urban part showed maximum population growth in past two decades. Increasing demand of housing in last few years is another reason for large settlements in these areas. In addition, market facility, shops and services have accelerates the rate of urban center shifting at PCMC. 
Factors causing urban center shift: The population density from earliest center was observed to be shifting around periphery due to new industrial development (Zhao \& Wang, 2015). These newly formed industrial zones towards the north of study area namely Talavade, Chakan and Talegaon (Figure 1) are of average 15 and $30 \mathrm{Km}$ from periphery and center respectively. The transport facility and accessibility, low cost of living (i.e. housing) around periphery region, opportunities for agricultural workers to get jobs in non-technical field since unavailability of farming land and a scope for expansion of administrative boundaries in future are the possible reasons for urban shift in northern part of study area.

The south western part of study area was similarly showing increasing population density i.e. shifting of urban centers. The presence of Hinjewadi IT park is causing this shift in last few years. High wages, improved lifestyle, and improved transport system facilitates rapid urban development (Baum-Snow, 2013) of this region. Hinjewadi IT park is the largest IT industry in India (CDP, 2006) providing jobs to more than two lack population. Large proportion of technical and non-technical working population of study area have been connected to this region. The distance from periphery to Hinjewadi IT park is about $7 \mathrm{Km}$. This all have made migration of people towards south western part and ultimately urban shift.

The increasing population densities at northern and southwestern part of study area have reached to its peak and establish itself as the new urban form and therefore, the new urban centers.

BMP for new urban growth centers: Use of population projection studies in long term planning can help to manage the needs of growing urban areas. The growing urban areas should consider a land development and urban environmental planning well in advance. The major environmental issues can get priority which includes water supply, solid waste management, waste water treatment, storm water drainages, public transport and roads etc. (Johnson, 2001; Wilson \& Chakraborty, 2013). The demands of new urban center shift presumed to be increases hence the geographical expansion and the limits of economical and political boundaries should be taken in consideration for such developing urban areas.

\section{Conclusion}

The rapid infrastructure growth can be viewed through residential growth, large road network and public services (water supply, sewage and waste disposal, slum, health and education), it boosts the population growth through migration from outside. Use of GIS, Remote sensing and Shannon entropy techniques are the suitable method of urban sprawl measurement. The leapfrog and ribbon strip type of urban sprawl can be ascertain from the residential growth at village centers, industrial areas, along roads, highways and railway line. Besides that increase of built up land and simultaneous decrease in agriculture land and waste land are witnessing urban growth.

The temporal changes observed from satellite image analysis can be useful in planning and decision making process of such rapidly growing city. The uncontrolled urban 
growth should be restricted through proper planning and management or else it impacts on natural environment (air, water, soil, noise pollution). Temporal changes of built-up land and population density change at the periphery regions proves shifting of urban center at study area.

\section{References}

Aguda, A. S., \& Adegboyega, S. A. (2013). Evaluation of Spatio-Temporal Dynamics of Urban Sprawl in Osogbo, Nigeria Using Satellite Imagery \& GIS Techniques. International Journal of Multidisciplinary and Current Research.

Alabi, M. O. (2009). Urban Sprawl, Pattern and Measurement in Lokoja, Nigeria. Theoretical and Empirical Researches in Urban Management.

Anderson, J. R., Hardy, E. E., Roach, J. R., \& Witmer, R. E. (1976). A Land Use and Land Cover Classification System for Use with Remote Sensor Data.

http://landcover.usgs.gov/pdf/anderson.pdf

Barnes, K. B., Morgan III, J. M., Roberge, M. C., \& Lowe, S. (2002). Sprawl Development: Its Patterns, Consequences, and Measurement. https://tigerweb.towson.edu/morgan/files/sprawl_development.pdf

Batty, M. (1974). Spatial Entropy. Geographical Analysis 2010, 6, Wiley Online Library, 1-31. http://dx.doi.org/10.1111/j.1538-4632.1974.tb01014.x

Baum-Snow, N. (2013). Changes in Urban Population Densities over the Next 40 Years. Cityscape: A Journal of Policy Development and Research, 15.

Bhatta, B. (2010). Analysis of Urban Growth and Sprawl from Remote Sensing Data. Springer, $172 \mathrm{p}$.

Bhatta, B., Saraswati, S., \& Bandyopadhyay, D. (2010). Urban Sprawl Measurement from Remote Sensing Data. Elsevier Applied Geography, 30, 731-740.

Brockerhoff, M. (1999). Urban Growth in Developing Countries: A Review of Projections and Predictions. Population and Development Review, 25, 757-778.

Bryant, C. (2003). The Impact of Urbanization on Rural Land Us. Encyclopedia of Life Support System. http://www.eolss.net

Carbal, P., Augusto, G., Tewolde, M., \& Araya, Y. (2013). Entropy in Urban Systems. Review, Entropy 2013, 15, 5223-5236. http://dx.doi.org/10.3390/e15125223

Census (2011). Provisional Population Totals Urban Agglomerations and Cities. http://censusindia.gov.in/2011

Champion, T. (2001). Urbanization, Suburbanization, Counter-Urbanization and Re-Urbanization. In R. Paddison (Ed.), Handbook of Urban Studies (pp. 143-160). http://dx.doi.org/10.4135/9781848608375.n9

City Development Plan (CDP) (2006). Pimpri Chinchwad 2006-2012 Jawaharlal Nehru National Urban Renewal Mission. www.pcmcindia.gov.in/jnnurm_info/cdpvol1.pdf

Cortright, J. (2015). City Report. http://cityobservatory.org

Dey, H. S., \& Greeshma, M. A. (2014). Built up Area Analysis of the Green Belt of Master Plan of Delhi (MPD)-2021 in GIS Platform. 15th Esri India User Conference, ESRI India.

Dobbs, R., \& Remes, J. (2012). Trends. The Shifting Urban Economic Landscape: What Does It Mean for Cities? http://siteresources.worldbank.org

Environmental Status Report (ESR 2012-2013). Draft Copy Pimpri Chinchwad Municipal Corporation. www.pcmcindia.gov.in/pdf/esr_eng_2013.pdf 
Environmental Status Report (ESR 2013-2014). Pimpri Chinchwad Municipal Corporation. www.pcmcindia.gov.in/pdf/ESR_English.pdf

Frenkel, A., \& Ashkenazi, M. (2008). Measuring Urban Sprawl: How Can We Deal with It? Environment and Planning B, Planning and Design, 35, 56-79. http://dx.doi.org/10.1068/b32155

Glaeser, E. L., \& Kahn, M. E. (2004). Sprawl and Urban Growth. In J. V. Henderson, \& J. E. Thisse (Eds.), Handbook of Regional and Urban Economics, Cities and Geography (Chap. 56, Vol. 4, pp. 2481-2527). Amsterdam: Elsevier.

Glaeser, E. L., Gyourko, J., \& Saks, R. E. (2005). Urban Growth and Housing Supply. http://www.nber.org/papers/w11097.pdf

Grigorescu, I., Mitrica, B., Mocanu, I., \& Ticana, N. (2012). Urban Sprawl and Residential Development in the Romanian Metropolitan Areas. Revue Roumaine de Géographie, 56, 43-59.

Guest, A. M., \& Brown, S. K. (2005). Population Distribution and Suburbanization. In D. L. Poston, \& M. Micklin (Eds.), Handbook of Sociology and Social Research (Chapter II, pp. 59-86). Berlin: Springer. http://dx.doi.org/10.1007/0-387-23106-4_3

Hermelin, B. (2007). The Urbanization and Suburbanization of the Service Economy: Producer Services and Specialization in Stockholm. Geografiska Annaler. Series B, Human Geography, 89, 59-74.

Johnson, M. P. (2001). Environmental Impacts of Urban Sprawl: A Survey of the Literature and Proposed Research Agenda. Environmental and Planning A, 33, 717-735. http://dx.doi.org/10.1068/a3327

Kotharkar, R., Bahadure, P., \& Sarda, N. (2014). Measuring Compact Urban Form: A Case of Nagpur City, India. Sustainability, 6, 4246-4272. http://dx.doi.org/10.3390/su6074246

Kumar, M. (2003). Digital Image Processing. In M. V. K. Sivakumar, P. S. Roy, K. Harmsen, \& S. K. Saha (Eds.), Satellite Remote Sensing and GIS Applications in Agricultural Meteorology, Dehra Dun, 7-11 July 2003, 81-102.

Lee, J. H. (2014). Handling Digital Images for Publication. Science Editing, 1, 58-61. http://dx.doi.org/10.6087/kcse.2014.1.58

Lie, C. L., \& Zhang, H. (2009). On the Characteristics of Housing Spatial Structure and Location Selection of Residential Communities: A Case Study of Wuhan City. Journal of Geography and Geology, 1, 7-19.

Lubis, J. P. G., \& Nakagoshi, N. (2011). Land Use Land Cover Change Detection Using Remote Sensing and Geographic Information System in Bodri Watershed, Central Java, Indonesia. Journal of International Development and Cooperation, 18, 139-151.

Mohammady, S., \& Delavar, M. R. (2015). Urban Sprawl Monitoring. Modern Applied Science, 9, $1-12$.

Nechyba, J. T., \& Walsh, R. P. (2004). Urban Sprawl. Journal of Economic Perspectives, 18, 177-200. http://dx.doi.org/10.1257/0895330042632681

Ramchandran, R. (2000). Public Access to Indian Geographical Data. Current Science, 79, 450467.

Sankhala, S., \& Singh, B. K. (2014). Evaluation of Urban Sprawl and Land Use Land Cover Change Using Remote Sensing and GIS Techniques: A Case Study of Jaipur City, India. International Journal of Emerging Technology and Advanced Engineering, 4, 66-72.

Shabu, T. (2010). The Relationship between Urbanization and Economic Development in Developing Countries. International Journal of Economic Development Research and Investment, 1 , 30-36.

Shekhar, S. (2004). Urban Sprawl Assessment: Entropy Approach. http://www.archidev.org 
Spence, M., Annez, P. C., \& Buckley, R. M. (Eds.) (2009). Urbanization and Growth. http://siteresources.worldbank.org

Sudhira, H. S., Ramachandra, T. V., \& Jagadish, K. S. (2004). Urban Sprawl: Metrics, Dynamics and Modelling Using GIS. International Journal of Applied Earth Observation and Geoinformation, 5, 29-39. http://dx.doi.org/10.1016/j.jag.2003.08.002

Tran, T. N. Q., Fanny, Q., de Claude, M., Vinh, N. Q., Nam, L. V., \& Truong, T. H., Eds. (2008). Trends of Urbanization and Suburbanization in Southeast Asia. Regional Conference "Trends of Urbanization and Suburbanization in Southeast Asia” (CEFURDS, LPED), Ho Chi Minh City, 9-11 December 2008, Ho Chi Minh City: Ho Chi Minh City General Publishing House, $328 \mathrm{p}$.

Tsai, Y.-H. (2005). Quantifying Urban Form: Compactness versus "Sprawl”. Urban Studies, 42, 141-161. http://dx.doi.org/10.1080/0042098042000309748

Weeks, J. R. (2010). Defining Urban Areas. In T. Rashed, \& C. Jurgens (Eds.), Remote Sensing of Urban and Suburban Areas, Remote Sensing and Digital Image Processing (Vol. 10, pp. 33-45). Netherlands: Springer. http://dx.doi.org/10.1007/978-1-4020-4385-7_3

Wilson, B., \& Chakraborty, A. (2013). The Environmental Impacts of Sprawl: Emergent Themes from the Past Decade of Planning Research. Review Sustainability, 2013, 3302-3327.

Yeh, A. G.-O., \& Li, X. (2001). Measurement and Monitoring of Urban Sprawl in Rapidly Growing Region Using Entropy. Photogrammetric Engineering \& Remote Sensing, 67, 83-90.

Zhao, J., \& Wang, C. D. (2015). Study on Spatial Distribution Feature of Industry Population of Taiyuan from 1990. International Conference on Education, Management and Computing Technology (ICEMCT 2015).

Zhou, Y. X. (1997). On the Suburbanization of Beijing. Chinese Geographical Science, 7, 208-219.

\section{Submit or recommend next manuscript to SCIRP and we will provide best service} for you:

Accepting pre-submission inquiries through Email, Facebook, LinkedIn, Twitter, etc.

A wide selection of journals (inclusive of 9 subjects, more than 200 journals)

Providing 24-hour high-quality service

User-friendly online submission system

Fair and swift peer-review system

Efficient typesetting and proofreading procedure

Display of the result of downloads and visits, as well as the number of cited articles

Maximum dissemination of your research work

Submit your manuscript at: http://papersubmission.scirp.org/

Or contact cus@scirp.org 